BASSOI, L.H.; FLORI, J.E.; SILVA, E.E.G.; SILVA, J.A.M. Guidelines for irrigation scheduling of peach palm for heart-of-palm production in the São Francisco Valley, Brazil. Horticultura Brasileira, Brasília, v. 21, n. 4, p. 681-685, outubro/dezembro 2003.

\title{
Guidelines for irrigation scheduling of peach palm for heart-of-palm production in the São Francisco Valley, Brazil
}

\author{
Luís Henrique Bassoi ${ }^{1}$; José Egídio Flori ${ }^{1}$; Emanuel Elder G. da Silva²; José Antonio M. e Silva ${ }^{2}$ \\ ${ }^{1}$ Embrapa Semi-Árido, C. Postal 23, 56302-970 Petrolina-PE, Brazil; ${ }^{2} \mathrm{CNPq}$ fellow, Embrapa Semi-Árido; E-mail: \\ lhbassoi@cpatsa.embrapa.br
}

\begin{abstract}
The water consumption, crop coefficient and effective rooting depth of the peach palm cultivated in a Vertisol were evaluated over two years and three months, from planting to fifth harvest, in Juazeiro, Bahia State, Brazil. Plants were irrigated by microsprinklers under two irrigation treatments, full irrigation (FI) and reduced irrigation (RI), and the amount of water applied in RI corresponded to $75 \%$ of that of FI. Water consumption and crop coefficient has increased markedly at the first harvest $\left(7.3 \mathrm{~mm}^{-1 a y}{ }^{-1}\right.$ and 1.2 , respectively, in FI treatment) in the thirteenth month, as a consequence of plant canopy development. After that, plants were harvested every three or four months, and these values varied a little due to decrease of the stand. The effective rooting depth was shallow $(40 \mathrm{~cm})$ at 12 months (before the first harvest) and it remained the same up to 24 months after planting (after the fourth harvest). Significant response of heartof-palm yield to the irrigation treatments was not observed.
\end{abstract}

Keywords: Bactris gasipaes Kunth, semi-arid, yield.

\section{RESUMO}

Recomendações para o manejo da irrigação da pupunha para a produção de palmito no Vale do São Francisco

O consumo de água, o coeficiente de cultura e a profundidade efetiva de raízes da pupunha cultivada em um Vertissolo foram estimados do plantio até a quinta colheita de palmito, durante dois anos e três meses, em Juazeiro-BA. As plantas foram irrigadas por microaspersão sob dois tratamentos, irrigação total (IT) e irrigação reduzida (IR), sendo a quantidade de água aplicada em IR correspondente a $75 \%$ daquela em IT. O consumo de água e o coeficiente de cultura aumentaram consideravelmente até a primeira colheita (7,3 $\mathrm{mm} \mathrm{dia}^{-1}$ e 1,2 , respectivamente, no tratamento IT) no décimo terceiro mês após o plantio, devido ao crescimento contínuo das plantas. Posteriormente, como os cortes foram realizados a cada três ou quatro meses, os valores de consumo de água e coeficiente de cultura apresentaram variações devido à redução do número de plantas por área. A profundidade efetiva das raízes foi de $40 \mathrm{~cm}$ aos $12 \mathrm{me}-$ ses (antes da primeira colheita) e permaneceu a mesma aos 24 meses após o plantio (após a quarta colheita). Não houve diferença significativa entre a produção de palmito de ambos os tratamentos de irrigação.

Palavras-chave: Bactris gasipaes Kunth, semi-árido, produção.

(Recebido para publicação em 14 de janeiro de 2003 e aceito em 12 de agosto de 2003)

$\mathrm{P}$ each palm (Bactris gasipaes Kunth) had a wide geographical distribution over the Central and South America (humid tropics) in the pre-Columbian times (Mora-Urpí et al. 1997). Other palms like Euterpe edulis Mart. and Euterpes oleracea Mart. have been exploited from natural areas for heart-ofpalm production at a predatory level, and since 1990 peach palm has become an alternative for this purpose due to its fast growth rate (Clement \& Bovi, 2000; Bovi et al., 2001). In the São Francisco Valley, semi-arid region of the Northeastern Brazil, the peach palm was introduced in 1991 for the heart-of-palm production, and rooting pattern, plant density, diameter of steam for harvesting and offshoots management were studied (Bassoi et al., 1999a; Drumond et al., 1999; Flori et al., 2001). The availability of high solar radiation (high air temperature) along the whole year, combined with the irrigation practice, make possible the peach palm cultivation in the Brazilian semi-arid region. As a perennial crop, peach palm needs approximately one and a half year until the first harvest of heart-of-palm in this region, and the following harvests can be achieved every three months (Flori et al., 2001). The guidelines for irrigation scheduling in this period of fast vegetative growing is so important as well as in the harvesting period for a rational water use. As such information related to the peach palm is not available for this semi-arid region, this research was carried out to study some useful guidelines for the irrigation practice in this crop.

\section{MATERIAL AND METHODS}

Site, planting and irrigation
system

An experiment was carried out at Embrapa Semi-Árido, in Juazeiro,
Brazil (latitude $09^{\circ} 24^{\prime \prime} \mathrm{S}$, longitude $40^{\circ}$ 26" W), from February 1999 (planting) to May 2001 (fifth harvest). Peach palm was planted in a $2 \times 1 \mathrm{~m}$ grid spacing in a Vertisol. Soil chemical and physical characteristics were determined as described by Embrapa (1997), in soil samples of $0.2 \mathrm{~m}$ thickness collected from surface to $1 \mathrm{~m}$ depth. Results showed a high clay content ( 350 to 310 , 200 to 250 , and 400 to $460 \mathrm{~g} \cdot \mathrm{kg}^{-1}$ of sand, silt and clay, respectively); low bulk density (1.19 to $\left.1.22 \mathrm{~kg} . \mathrm{dm}^{-3}\right)$; high soil water holding capacity ( 0.293 to 352 and 0.124 to $0.183 \mathrm{~m}^{3} \mathrm{~m}^{-3}$ at 10 and 1500 $\mathrm{kPa}$, respectively); low alkalinity ( $\mathrm{pH}$ 7.8 to 8.0$)$; low electric conductivity

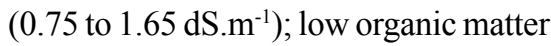
content (18.8 to 9.3 g. $\left.\mathrm{dm}^{-3}\right)$; high contents of calcium (26.7 to 29.0 cmol $\left.\mathrm{dm}^{-3}\right)$, potassium (0.3 to 0.1 $\mathrm{cmol}_{\mathrm{c}} \mathrm{dm}^{-3}$ ), and phosphorus (46 to 27 
mg. $\left.\mathrm{dm}^{-3}\right)$; medium content of magnesium ( 2.9 to $1.3 \mathrm{cmol}_{\mathrm{cm}} \mathrm{dm}^{-3}$ ) high cationic exchange capacity (28.9 to 31.3 ); and high base saturation (100\%). The crop was irrigated by microsprinkler, with emitter lines spaced in $4 \mathrm{~m}$ and emitters spaced in 2 $\mathrm{m}$ inside the line. So, there were interrow spaces with and without water emitter lines. Microsprinklers with two different flowrates, $39.8 \mathrm{~L} \mathrm{~h}^{-1}$ and 29.6 $\mathrm{L} \mathrm{h}^{-1}$ at $150 \mathrm{kPa}$, were used to evaluate the full irrigation (treatment FI) and the reduced irrigation (treatment $\mathrm{RI}$ ) on plant yield, respectively. Field tests were performed to estimate the wetted radius $(2 \mathrm{~m})$ and the flowrates mentioned. The water application diameter of the microsprinklers promoted the wetting of the total soil surface among plants, and the plots of both treatments were irrigated simultaneously. The experimental area was composed of twenty and eight rows with twenty plants $\left(1120 \mathrm{~m}^{2}\right)$, and each of the seven blocks was composed of four rows (two of them as boundary). The irrigation main line crossed through the area dividing all blocks in two halves (plots) of four rows with ten plants, and irrigation treatments were randomly arranged in each block. No offshoots management was adopted.

Two tensiometer sets installed in each irrigation treatment (devices installed at $0.2 ; 0.4 ; 0.6 ; 0.8$, and $1.0 \mathrm{~m}$ depths) determined the soil matric potential $\left(\psi_{\mathrm{m},} \mathrm{kPa}\right)$. Early morning readings of these devices were performed three times a week. Disturbed soil samples of $0.2 \mathrm{~m}$ thickness were collected for determination of the soil water retention curve used to estimate the soil water content $\left(\theta, \mathrm{m}^{3} \mathrm{~m}^{-3}\right)$. The $\psi_{\mathrm{m}}(\mathrm{q})$ relationship was described by the model proposed by van Genuchten (1980).

The net irrigation amount $\left(\mathrm{A}_{\mathrm{n}}, \mathrm{mm}\right)$ was calculated by

$$
A_{n}=\left(\theta_{F C}-\theta_{a}\right) \cdot \Delta z \cdot 1000
$$

where $\theta_{\mathrm{FC}}$ and $\theta_{\mathrm{a}}$ were considered the soil water content $\left(\mathrm{m}^{3} \mathrm{~m}^{-3}\right)$ at the field capacity matric potential $(-10 \mathrm{kPa})$ and at the actual matric potential, respectively, and $\Delta z$ was the soil depth (m). The critical or minimum matric potential adopted was around $-30 \mathrm{kPa}$
(40\% of soil water depletion) until 0.4 $m$ depth to allow high soil water availability. The irrigation frequency was dependent on soil water status and also on rainfall, but in most of the time, it was two days.

The gross irrigation amount $\left(\mathrm{A}_{\mathrm{g}}\right.$, $\mathrm{mm}$ ) was calculated by

$$
A_{g}=A_{n} / E_{f}
$$

where $E_{f}$ is the irrigation efficiency (adopted as 0.9).

The irrigation time $(\mathrm{Ti}, \mathrm{h})$ was calculated by

$$
\mathrm{Ti}=\left(\mathrm{A}_{\mathrm{g}} \cdot \mathrm{E} 1 . \mathrm{E} 2 \cdot \mathrm{P}\right) /(\mathrm{n} . \mathrm{F})
$$

where E1 and E2 are the spacing between plants $(2 \times 1 \mathrm{~m}), \mathrm{P}$ is the percentage of wetted soil surface (1), $n$ is the number of emitters per plant $(0.25)$, and $F$ is the microsprinkler flowrate $\left(\mathrm{L} \cdot \mathrm{h}^{-1}\right)$. The q value of $39.8 \mathrm{~L}$ $\mathrm{h}^{-1}$ was considered in the Ti calculation. So, plots from RI treatment had a $25 \%$ reduction of the amount of water applied.

\section{Root system analysis}

The root system distribution of the peach palm was analyzed at $6 ; 12$ and 24 months after planting. In the two first evaluations, trenches $(1 \mathrm{~m}$ deep, $2 \mathrm{~m}$ wide) were dug longitudinally to the plant row to expose a half root system of two plants in both treatments. The distance between the trench wall and the plant row was $1 \mathrm{~m}$. A thin layer of soil $(1-2 \mathrm{~cm})$ was carefully removed from the excavated profile wall along the whole trench, and visible roots (greater generally with diameter larger than 1 $\mathrm{mm}$ ) were painted with white ink to enhance color contrast of the roots and the soil. A 1x1 m wire-wood frame with a wire grid of $0.2 \times 0.2 \mathrm{~m}$ was pressed on against the trench wall and pictures were taken with a digital camera (resolution of $640 \times 480$ pixels) for each of $0.04 \mathrm{~m}^{2}$ areas along the whole trench. After that, the a soil thickness of $0.02 \mathrm{~m}$ was excavated and another trench wall was obtained. Thus, pictures were repeated at distances of $1.0 ; 0.8 ; 0.6 ; 0.4$; and $0.2 \mathrm{~m}$ from the plant rows. At 24 months after planting, four plants of the FI treatment were analyzed and trenches (1 $\mathrm{m}$ deep, $2 \mathrm{~m}$ wide) were dug transversally to the plant row to compare the roots of both sides (with microsprinkler and not) only at the distance of $0.2 \mathrm{~m}$ from the plant. The pictures were saved as BMP files and processed by the Integrated System for Root and Soil Coverage Analysis (SIARCS ${ }^{\circledR}$ ) software- (Crestana et al., 1994; Bassoi et al., 1999b). In From each image, root length in the soil profile $\left(\mathrm{L}_{\mathrm{p}}, \mathrm{m}\right)$ was measured. The root system parameter was integrated over the depth and the distance from the plant and the percentage distributions in vertical and horizontal directions were calculated, respectively.

\section{Water balance in situ}

In the two irrigation treatments, the water balance for a specific period of time was performed from February 1999 to May 2001 to estimate ETc

$\mathrm{Ra}+\mathrm{I} \pm \mathrm{q}_{\mathrm{i}} \pm \Delta \mathrm{S} \pm \mathrm{Ru}-\mathrm{ETc}=0$

where $\mathrm{Ra}$ is the rainfall, $\mathrm{I}$ is the amount of water applied in every irrigation event, $\mathrm{q}_{\mathrm{i}}$ is the downward or upward water flux, DS is the changing of soil water storage $(\mathrm{S}), \mathrm{Ru}$ is the runoff, and ETc is the crop evapotranspiration (Reichardt, 1996). Ra was obtained from a pluviometer in the experimental field weather station, while I was determined from the $\mathrm{Ti}$ calculated for every irrigation event in FI and RI treatments. Ru was considered negligible due to the flat topography of the area. All values from water balance equation were expressed in $\mathrm{mm}$.

The component $\mathrm{q}_{i}$ was obtained from the integration of $\mathrm{q}_{\mathrm{z}}$ values estimated by the Darcy-Buckingham equation

$$
\mathrm{q}_{\mathrm{i}}=\int_{\mathrm{t} 1}^{\mathrm{t} 2} \mathrm{q}_{\mathrm{z}} \mathrm{dt}=\int_{\mathrm{t} 1}^{\mathrm{t} 2}-\mathrm{K}(\theta) \nabla \psi_{\eta} \mathrm{dt}
$$

where $\mathrm{q}_{\mathrm{z}}$ is the soil water flux density $\left(\mathrm{q}, \mathrm{m}^{3} \mathrm{~m}^{-2} \mathrm{day}^{-1}\right)$ in the direction $\mathrm{z}$ (vertical) between time $\mathrm{t} 1$ and time $\mathrm{t} 2$, $K(\theta)$ is the unsaturated hydraulic conductivity-soil water content relationship (m day $\left.{ }^{-1}\right)$, and $\nabla \psi_{\mathrm{h}}$ is the hydraulic gradient (dimensionless) in the direction $\mathrm{z}$.

The hydraulic conductivity was estimated by the method proposed by Libardi et al. (1980), and represented by the equation

$$
\mathrm{K}(\theta)=\mathrm{K}_{\mathrm{o}} \mathrm{e} \beta\left(\theta^{-} \theta^{\circ}\right)
$$

where $\mathrm{K}_{\mathrm{o}}$ is the saturated hydraulic conductivity ( $\mathrm{m}$ day $\left.{ }^{-1}\right), \beta$ is the coefficient 
dependent of the soil and determined by equation regression, and $\theta$ and $\theta_{0}\left(\mathrm{~m}^{3} \mathrm{~m}^{-3}\right)$ are the actual and saturated soil water content, respectively. The relationship $\mathrm{K}(\theta)$ was determined closed to the experimental area, in a $5 \times 5 \mathrm{~m}$ plot, which was saturated with water in the $1.5 \mathrm{~m}$ soil depth and covered to avoid soil water evaporation. Three neutron probe access tubes were installed in the middle of this plot to monitor the $\theta$ changing over the time by the neutron scattering technique. The neutron probe was previously calibrated in the same soil by regression of $\theta$ data (determined by the gravimetric method) with device readings in dry and wet plots.

The positive and negative values of the hydraulic gradient indicated downward and upward flux, respectively. The $\nabla \psi_{\mathrm{h}}$ values were estimated by the ratio difference of hydraulic potential $\left(\psi_{\mathrm{h}}, \mathrm{KPa}\right)$ between one depth above and another below the depth of $0.6 \mathrm{~m}$, divided by the distance between them $(\Delta \mathrm{z}, \mathrm{m})$

$$
\nabla \psi_{\mathrm{h}}=\left(\psi_{\mathrm{h} \text { above }}-\psi_{\mathrm{h} \text { below }}\right) / \Delta \mathrm{z}
$$

The soil water storage $(\mathrm{S}, \mathrm{mm})$ was obtained by the $\theta$ integration from the soil depths monitored by tensiometers, and the changing $(\Delta \mathrm{S}, \mathrm{mm})$ was estimated from the difference between the $\mathrm{S}$ in the end $\left(\mathrm{S}_{\mathrm{t} 2}\right)$ and in the beginning $\left(\mathrm{S}_{\mathrm{t} 1}\right)$ of a specific period of time

$$
\mathrm{S}=\int^{\mathrm{Z}} \theta(\mathrm{z}) \mathrm{dz}
$$

0

$$
\Delta \mathrm{S}=\mathrm{S}_{\mathrm{t} 2}-\mathrm{S}_{\mathrm{t} 1}
$$

Reference evapotranspiration, crop evapotranspiration and crop coefficient

The daily reference evapotranspiration (ETo, mm) was estimated by the evaporation pan class A (Allen et al., 1998)

$$
\mathrm{ETo}=\mathrm{Ep} \cdot \mathrm{Kp}
$$

where Ep is the daily pan evaporation, and $\mathrm{Kp}$ is the pan coefficient based on wind velocity, relative air humidity, and pan boundary of the local weather station.

\section{Plant and yield measurements}

At each harvest, some measurements were taken (Clement \& Bovi, 2000): height of the petiole insertion of the lower leaf (essential vegetative measurement); stem diameter (optimal vegetative measurement); number and fresh weight of cylindrical, straight, 9 cm long, export type heart-of-palm (essential yield measurement). The stem diameter of $10 \mathrm{~cm}$ was considered as the minimum diameter for harvesting (Flori et al. 2001).

\section{Statistical procedures}

The root parameter $\mathrm{L}_{\mathrm{p}}$ for the two irrigation treatments was analyzed in relation to five soil depths $(0-0.2 ; 0.2-$ 0.4 ; $0.4-0.6$; $0.6-0.8$; and $0.8-1.0 \mathrm{~m})$ using a repeated measure design. As measurements were repeated over the soil profile, the root count at one depth (soil layer of $0.2 \mathrm{~m}$ thickness) is not independent on the root count of the next depth, for a homogeneous soil. So, counts over several depths were considered repeated spatial measurements (Morano \& Kliewer, 1994). For each irrigation treatment, sampling was performed with two (6 and 12 months) and four (24 months) replications.

The analysis of variance for the yield component (fresh weight of heart-ofpalm, obtained by the product of amount $\mathrm{x}$ weight) was performed against the two irrigation treatments (FI and RI) in a seven randomized blocks design. The dependence of yield obtained along the time (five harvests in the same plots) was considered, i.e., in an accumulative way, as recommended for the analysis of perennial crop data (Pearce, 1976; Ramalho et al., 2000). On the other hand, the analysis of variance of steam diameter and height of the petiole insertion of the lower leaf were performed against the same treatments for each harvesting time, also in a seven randomized block design.

\section{RESULTS AND DISCUSSION}

The water consumption was greater for the fully irrigated plants (FI). For both treatments, the water consumption and $\mathrm{Kc}$ values increased from the planting $-6^{\text {th }}$ month period to the $7^{\text {th }}$ $13^{\text {th }}$ month period, as a consequence of the plant canopy growing. After the $1^{\text {st }}$ harvest on March 2000 (13 ${ }^{\text {th }}$ month), both values presented no changes for the following three months until the $2^{\text {nd }}$ harvest on June 2000. But a decrease of these values was observed in the next two harvests $\left(3^{\text {rd }}\right.$ and $4^{\text {th }}$, respectively on October 2000 and February 2001), and lower water consumption and Kc were found in the $5^{\text {th }}$ harvest on May 2001 (Table 1). For drip irrigated peach palm, cultivated in the same spacing grid of this study, Lopes et al. (2000) recommended the Kc equal to 1.0 for one year old plants (latitude $20^{\circ} 22^{\prime \prime} \mathrm{S}$, longitude $51^{\circ} 22$ " W), while Ramos (1998) found a range of 0.56 to 1.35 (from autumn to summer) and an average value of 0.92 for three-year old plants (latitude $22^{\circ} 42^{\prime} \mathrm{S}$, longitude $47^{\circ}$ 30" W).

The greatest Kc values and the lack of remarkable changing until the $2^{\text {nd }}$ harvest are justified by the greatest yield of heart-of-palm in the first two harvests. In the $3^{\text {rd }}$ harvest (October 2000), the stems with diameters equal or greater than $10 \mathrm{~cm}$ were not observed in some plots. The accumulated rainfall from October 1999 to April 2000 was 670.7 $\mathrm{mm}$, and the high clay content of this soil allowed high soil water storage over a long period of time. This soil condition was favorable to the occurrence of Erwinia, which caused the softrot of basal leaves in some plants and the offshoot death. The bacteria from plant samples were identified in the phytopathology laboratory. Consequently, the yield reduced in October 2000, and the water consumption and the $\mathrm{Kc}$ values also reduced between July and October 2000 . Hence, the irrigation management was modified to reduce the bacteria presence in the soil by adopting another value of critical matric potential (- $50 \mathrm{kPa}$ which corresponds to nearly $50 \%$ of soil water depletion), and the yield increased in the $4^{\text {th }}$ harvest (February 2001) in both irrigation treatments, as well as the water consumption.Hence, the irrigation management was modified to reduce another value of critical matric potential $(-50 \mathrm{kPa}$ which corresponds to nearly $50 \%$ of soil water depletion), and the yield increase in the $4^{\text {th }}$ harvest (February 2001) in both irrigation treatments, as well as the water consuption. On May 2001 ( $5^{\text {th }}$ harvest $)$, the criteria stem diameter equal or 
Table 1. Crop evapotranspiration (ETc, mm), average evapotranspiration (avg ETc, mm day ${ }^{-1}$ ), reference evapotranspiration (ETo, mm) and crop coefficient (Kc) of the peach palm crop under two irrigation amounts (RI and FI). Juazeiro, Embrapa Semi-Árido, $1999-2001$.

\begin{tabular}{lcccccccc}
\hline \multirow{2}{*}{ Harvest date } & \multicolumn{2}{c}{ ETc } & \multicolumn{2}{c}{ avg ETc } & \multirow{2}{*}{ ETo } & \multicolumn{3}{c}{ Kc } \\
\cline { 2 - 4 } & RI & FI & RI & FI & & RI & FI \\
\hline 1 to 6 (Feb - Aug 1999) & 509.4 & 664.9 & 2.9 & 3.8 & 862.8 & 0.6 & 0.8 \\
7 to 13 (Sep 1999 - Mar 2000) & 1242.0 & 1295.2 & 5.8 & 6.0 & 1262.6 & 0.9 & 1.2 \\
14 to 16 (Apr - Jun 2000) & 524.6 & 657.2 & 5.8 & 7.2 & 453.8 & 0.9 & 1.2 \\
17 to 20 (Jul - Oct 2000) & 454.2 & 555.3 & 3.8 & 4.6 & 682.8 & 0.7 & 0.9 \\
21 to 24 (Nov 2000 - Feb 2001) & 538.7 & 722.5 & 4.5 & 6.1 & 687.6 & 0.6 & 0.9 \\
25 to 27 (Mar - May 2001) & 173.4 & 236.1 & 2.0 & 2.7 & 508.5 & 0.4 & 0.5 \\
\hline total & 3542.5 & 4424.5 & - & - & 4458.3 & - & - \\
\hline average & - & - & 4.3 & 5.1 & - & 0.7 & 1.0 \\
\hline
\end{tabular}

Table 2. Average values of diameter, height of petiole of the lower leaves, amount, fresh weight and yield of heart-of-palm $(9 \mathrm{~cm}$ long, cylindrical, straight, extra type), in the five harvest dates. Juazeiro, Embrapa Semi-Árido, 1999-2001.

\begin{tabular}{lcccccc}
\hline $\begin{array}{c}\text { Months after } \\
\text { planting }\end{array}$ & Irrigation & $\begin{array}{c}\text { Diameter } \\
\mathbf{c m}\end{array}$ & Height ${ }^{\text {ns } 1} \mathbf{m}$ & Amount & Weight g & Yield kg.ha-1 $^{-1}$ \\
\hline $13^{*}$ & $\mathrm{RI}$ & $11.1 \pm 1.1$ & $1.7 \pm 0.2$ & 8631 & $71.8 \pm 20.5$ & 598 \\
& $\mathrm{FI}$ & $10.9 \pm 0.8$ & $1.6 \pm 0.2$ & 9643 & $70.3 \pm 17.9$ & 663 \\
$16^{*}$ & $\mathrm{RI}$ & $11.1 \pm 0,9$ & $1.7 \pm 0.2$ & 5119 & $69.4 \pm 24.3$ & 343 \\
& $\mathrm{FI}$ & $11.7 \pm 1.1$ & $1.7 \pm 0.3$ & 5060 & $68.8 \pm 16.5$ & 348 \\
$20^{*}$ & $\mathrm{RI}$ & $10.6 \pm 0.7$ & $1.4 \pm 0.2$ & 1310 & $51.8 \pm 14.9$ & 67 \\
& $\mathrm{FI}$ & $10.7 \pm 0.6$ & $1.6 \pm 0.2$ & 655 & $62.5 \pm 14.0$ & 40 \\
$24^{*}$ & $\mathrm{RI}$ & $10.5 \pm 1.0$ & $1.6 \pm 0.2$ & 3869 & $57.4 \pm 11.6$ & 215 \\
& $\mathrm{FI}$ & $10.4 \pm 0.7$ & $1.5 \pm 0.2$ & 2679 & $59.6 \pm 14.3$ & 153 \\
$27^{*}$ & $\mathrm{RI}$ & $9.3 \pm 0.5$ & $1.4 \pm 0.2$ & 2679 & $45.8 \pm 13.7$ & 121 \\
& $\mathrm{FI}$ & $9.2 \pm 0.4$ & $1.2 \pm 0.1$ & 3095 & $49.5 \pm 14.3$ & 150 \\
\hline \multirow{2}{*}{ total } & $\mathrm{RI}$ & - & - & 21607 & - & $13455^{\text {ns } 2}$ \\
& $\mathrm{FI}$ & - & - & 21131 & - & $13544^{\text {ns 2 }}$ \\
\hline
\end{tabular}

* - significant differences among harvest times at 1\% of probability; ns 1 - differences not significant between treatments in each harvesting time; ns 2 - no significant differences of total harvest between irrigation treatments

greater than $10 \mathrm{~cm}$ was not considered for harvesting (Table 2). Soil compaction, water saturation, and poor drainage, as a consequence of bulk density and porosity status, have an important negative influence over the peach palm development (Jorge \& Bovi, 1994; Bovi et al., 1997).

A remarkable leaf color and plant height variation was visible among plots within each irrigation treatment, mainly after the first harvest. The stem diameter and height of lower leaves of both treatments did not differ in each harvesting time. The yield of all harvest dates was 1345 and $1354 \mathrm{~kg} \mathrm{ha}^{-1}$ in the RI and FI treatments, respectively. The differences among harvesting times were significant $(p<0.01)$, but differences between irrigation treatments were not (Table 2). The high water storage of the clayey soil during the first year in both irrigation treatments (tensiometer data not shown), together with the genetic variability of the peach palm (Clement, 1987; Mora-Urpí, 1993; Mora-Urpí et al., 1997), i.e., plants with markedly difference of production potential, probably contributed to the lack of response for the water reduction.

For both irrigation treatments, the effective ( $80 \%$ or more of all roots) and the maximum rooting depths were, respectively, $0.2 \mathrm{~m}$ and $0.4 \mathrm{~m}$ at 6 months, and $0.4 \mathrm{~m}$ and $1.0 \mathrm{~m}$ at 12 and 24 months after planting. There was observed a sharp decrease of root presence between $0.2-0.4$ and $0.4-0.6 \mathrm{~m}$ depths, and few roots (less than 1\%) at $0.8-1.0 \mathrm{~m}$ depth. Inside the inter-rows, the maximum distance achieved by the roots in the horizontal direction was 0.6 $\mathrm{m}$ at 6 months, of which $90 \%$ were at $0.4 \mathrm{~m} .12$ months after planting, the maximum distance was $1.0 \mathrm{~m}$, where $80 \%$ of roots were at $0.8 \mathrm{~m}$, and this distribution indicated the root crossing over already in the $2^{\text {nd }}$ evaluation. The total rainfall from February to March 1999 was $149 \mathrm{~mm}$, and together with the irrigations, allowed a high water storage in the clayey soil since planting on February 1999. So, differences in root length of both treatments were observed 
only at 12 months after planting, one month before the $1^{\text {st }}$ harvest. The total root length was higher by t test $(\mathrm{p}<0.05)$ in the FI treatment. At 24 months, after four harvests, the roots of FI plants were distributed on both sides of the row (with microsprinkler line and not), and no differences were observed. Earlier, Bassoi et al. (1999a) observed the shallow rooting pattern (effective and maximum rooting depth of 0.4 and 0.8 $\mathrm{m}$, respectively) of three-year furrow irrigated peach palm in the same soil, but not when the root crossing over happened.

In the São Francsico Valley, average water consumption of microsprinkler irrigated peach palm increased from 3.8 $\mathrm{mm}$ day $^{-1}$ from planting to the $6^{\text {th }}$ month, and to $6.0 \mathrm{~mm}$ day $^{-1}$ until the $13^{\text {th }}$ month after planting ( $1^{\text {st }}$ harvest) as a consequence of the canopy growing. Respectively, the crop coefficient also increased from 0.8 to 1.2 . The values changed a little (7.2 mm day ${ }^{-1}$ and 1.2) until the $2^{\text {nd }}$ harvest, three months later. Decreases of plant density reduced the average water consumption and crop coefficient. The genetic variation observed in the peach palm crop produced plants with high height and leaf color variations, and the reduction by $25 \%$ of the gross amount of irrigation did not affect significantly the heart-of-palm production. In a clayey soil, the effective rooting depth was $40 \mathrm{~cm}$ before the $1^{\text {st }}$ harvest and remained the same until the $5^{\text {th }}$ harvest, fourteen months later.

\section{ACKNOWLEDGMENTS}

To Prodetab (BIRD-Embrapa agreement), which supported this research work (project no 123-01/97).

\section{CITED LITERATURE}

ALLEN, R.G.; PEREIRA, L.S.; RAES, D.; SMITH, M. Crop evapotranspiration. Guidelines for computing crop water requirements. Rome: FAO, 1998. 300 p (Irrigation and Drainage, 56).
BASSOI, L.H.; FLORI, J.E.; ALENCAR, C.M.; SILVA, J.A.M.; RAMOS, C.M.C. Distribuição espacial do sistema radicular da pupunheira em solos irrigados no Vale do São Francisco. Engenharia Agrícola, Jaboticabal, v. 19, n. 2, p. 163 176, 1999a

BASSOI, L.H.; SILVA, J.A.M.; ALENCAR, C.M.; RAMOS, C.M.R; JORGE, L.A.C.; HOPMANS, J.W. Digital image analysis of root distribution towards improved irrigation water and soil management. In: AMERICAN SOCIETY OF AGRICULTURAL ENGINEERING ANNUAL INTERNATIONAL MEETING, 1999, Toronto. Proceedings..., St Joseph: ASAE, 1999b. 5 p. (CD ROM paper 992225)

BOVI, M.L.A.; VIEIRA, S.R.; SPIERING, S.H.; MONTEIRO, S.M.G.; GALLO, P.B. Relações entre crescimento de pupunheira e alguns parâmetros físicos do solo. IN: CONGRESSO BRASILEIRO DE CIÊNCIA DO SOLO, 26. 1997, Rio de Janeiro. Anais..., Viçosa: SBCS, 1997. 4 p. (CD-ROM).

BOVI, M.L.A.; SAES, L.A.; UZZO, R.R.; SPIERING, S.H. Adequate timing for heart-ofpalm harvesting in King palm. Horticultura Brasileira, Brasília, v. 19, n. 2, p. 135-139, 2001.

CLEMENT, C.R. A pupunha, uma árvore domesticada. Ciência Hoje, Rio de Janeiro, v. 5, n. 29 p. 41-49, 1987.

CLEMENT, C.R.; BOVI, M.L.A. Padronização de medidas de crescimento e produção em experimentos com pupunheira para palmito. Acta Amazonica, Manaus, v. 30, n. 3, p. 349-362, 2000. CRESTANA, S.; GUIMARÃES, M.F.; JORGE, L.A.C., RALISH, R.; TOZZI, C.L.; TORRE, A.; VAZ, C.M.P. Avaliação da distribuição de raízes no solo auxiliada por processamento de imagens digitais. Revista Brasileira de Ciência do Solo, Campinas, v. 18, n. 3, p. 365-371, 1994.

DRUMOND, M.A.; FLORI, J.E.; FARIA, C.M.B.; D'OLIVEIRA, L.O.B. Produção e distribuição de biomassa e nutrientes em pupunha cultivada sob irrigação na região semi-árida do Nordeste brasileiro. Revista Árvore, Viçosa, v. 23 n. 4, p. 493-496, 1999.

EMPRESA BRASILEIRA DE PESQUISA AGROPECUÁRIA. Manual de métodos de análise de solo. 2. ed. Rio de Janeiro: EMBRAPA, CNPS, 1997. 212 p.

FLORI, J.E.; RESENDE, G.M.; DRUMOND, M.A. Rendimento do palmito de pupunha em função da densidade de plantio, diâmetro de corte e manejo dos perfilhos no Vale do São Francisco. Horticultura Brasileira, Brasília, v. 19, n. 2, p. 140-143, 2001.

JORGE, J.A.; BOVI, M.L.A. Influência das propriedades físicas e químicas do solo no crescimento da palmeira pupunha. In: CONGRESSO BRASILEIRO DE FRUTICULTURA, 13., 1994, Salvador. Resumos... Salvador: SBF, 1994. p. 1145 1146 .
LIBARDI, P.L.; REICHARDT, K.; NIELSEN, D.R.; BIGGAR, J.W. Simple field methods for estimating soil hydraulic conductivity. Soil Science Society of America Journal, Madison, v. 44, n. 1, p. 3-7, 1980.

LOPES, A.S.; HERNANDEZ, F.B.T.; ALVES JÚNIOR, J.; VALÉRIO FILHO, W.V. Manejo da irrigação na cultura da pupunha (Bactris gasipae H.B.K.) no noroeste paulista. In: CONGRESSO BRASILEIRO DE ENGENHARIAAGRÍCOLA, 29, 2000, Fortaleza. Anais...Fortaleza: SBEA, 2000 (CD-ROM)

MORA-URPI, J. Diversidade genética en pejibaye [Bactris (Guilielma) gasipaes Kunth] : II. Origen y domesticación. In: CONGRESSO INTERNACIONAL SOBRE BIOLOGIA, AGRONOMIA E INDUSTRIALIZACION DEL PIJUAYO, 4., 1991, Iquitos. San Jose: Editorial de la Universidad de Costa Rica, 1993. p. 21-29.

MORA-URPÍ, J.; WEBER, J.C.; CLEMENT, C.R. Peach palm. Bactris gasipaes Kunth. Promoting the conservation and use of underutilized and neglected crops. 20. Gatersleben: Institute of Plant Genetics and Crop Plant Research, Rome: International Plant Genetic Resources Institute, $1997.83 \mathrm{p}$.

MORANO, L.; KLIEWER, W.M. Root distribution of three grapevine rootstocks grafted to Cabernet sauvignon grown on a very gravelly clay loam soil in Oakville, California. American Journal of Enology and Viticulture, Davis, v. 45, n. 3, p. 345-348, 1994.

PEARCE, S.C. The measurement of perennial plants. IN: PEARCE, S.C. Field experimentation with fruit trees and other perennial plants. 2 ed. Farnham Royal: Commonwealth Agricultural Bureaux, 1976. p. 119-133 (Technical Communication, 23)

RAMALHO, M.A.P.; FERREIRA, D.F.; OLIVEIRA, A.C. Análise de grupos de experimento-análise conjunta. IN: RAMALHO, M.A.P.; FERREIRA, D.F.; OLIVEIRA, A.C. Experimentação em genética e melhoramento de plantas. Lavras: UFLA, 2000. p. 115-136.

RAMOS, A. Desenvolvimento vegetativo da pupunheira (Bactris gasipaes Kunth) irrigada por gotejamento em função de diferentes níveis de depleção de água no solo. Piracicaba: ESALQ, 1998. 66 p. (Tese mestrado).

REICHARDT, K. Dinâmica da matéria e energia em ecossistemas. Piracicaba: USP/ESALQ Depto Física e Meteorologia, 1996. 505 p.

VAN GENUCHTEN, M.T. A closed-form equation for predicting the hydraulic conductivity of unsaturated soils. Soil Science Society of American Journal, Madison, v. 44, n. 1, p. 898982, 1980. 